\title{
Social Justice Through Civil Justice
}

\author{
Geoffey C. Hazard, Jr.†
}

An important assumption underlying the Office of Economic Opportunity (OEO) Legal Services Program is that enforcement of legal rights through litigation can significantly improve the situation of the poor. The assumption seems valid on commonsense grounds, since it is evident that litigation can improve the situation of an individual client, rich or poor, for restitution or redress is after all the essential objective of a lawsuit; it would seem equally evident that the same proposition would hold for the poor as a group. The analysis here suggests that this is not true without substantial reservations and qualifications. If sound, this conclusion has immediate policy significance in the operation of the Legal Services Program.

The objectives of the Legal Services Program (LSP) have never been officially stated in very coherent terms. The Economic Opportunity Act of 1964 creating OEO did not explicitly authorize a program of legal services; ${ }^{1}$ the renewal legislation ratified LSP without explaining it. ${ }^{2}$ The diverse supporters of LSP, ranging from the organized bar to

$\uparrow$ Executive Director, American Bar Foundation, and Professor of Law, the University of Chicago. This paper is one of several emanating from studies done by the American Bar Foundation under contract from the Office of Economic Opportunity, CAP 67-7075, Research Contract No. OEO-4047. The author expresses special appreciation for their comments and criticisms to Walter Blum of the University of Chicago, Fred Cohen of the University of Texas, Barbara Curran of the American Bar Foundation, Sheldon Messinger of the Center for Study of Law and Society, University of California, Berkeley, and Quin Denvir, a student in the Law School of the University of Chicago. The views stated are those of the author and do not represent those of the Office of Economic Opportunity or the American Bar Foundation, its officers and directors, or others associated with its work.

1 Economic Opportunity Act of 1964 \$ 202(a), 42 U.S.C. $\$ 2782$ (a) (1964):

The term "community action program" means a program-

…

(2) which provides services, assistance, and other activities of sufficient scope and size to give promise of progress toward elimination of poverty or a cause or causes of poverty ....

2 Economic Opportunity Amendments of 1967 \&222(a), 42 U.S.C. $\$ 2809$ (a) (Supp. IV, 1969):

Programs under this section shall include those described in the following paragraphs:

(3) A "Legal Services" program to further the cause of justice among persons living in poverty by mobilizing the assistance of lawyers and legal institutions and by providing legal advice, legal representation, counseling, education, and other appropriate services. 
legal elements of the New Left, found it useful in arguing for the Program to submerge their differences over its policy. ${ }^{3}$ Accordingly, there have been perhaps as many opinions about the Program's chief purposes as commentators on it. Nevertheless, it is possible to discern four distinct concepts of the Program.

The most radical concept visualized the Legal Services Program offices as the nuclei of the Community Action Program. There were to be neighborhood-center locations, staffs of politico-legal sophisticates to develop and energize community self-help effort, and a pervasive program of organization-education-action-reform. This approach excited doubt and hostility in quarters where opposition would have been fatal to LSP, in particular the organized bar and a number of city governments including Chicago. Accordingly, it was implemented only in a few communities and even there has had a tenuous existence.

The most conservative approach, expressed in certain sectors of the bar and also "implemented" in certain areas, was even simpler: There shouldn't be a Legal Services Program, because such a program was unnecessary (the poor had no legal problems, or their legal problems were already being taken care of) and essentially socialistic.

Two intermediate concepts of a Legal Services Program therefore contended for primacy in the main thrust of the Program. One such concept was that expressed by the American Bar Association (ABA), which explained LSP to itself and to others as an expansion of traditional Legal Aid. 4 This may be taken as implying a generally conserva-

3 See, e.g., Joint Prepared Statement of Orison S. Marden, President, American Bar Ass'n; Revius O. Ortique, Jr., President, National Bar Ass'n; Maynard J. Toll, President, National Legal Aid and Defender Ass'n; John D. Robb, Chairman, American Bar Ass'n Standing Committee on Legal Aid and Indigent Defendants, Hearings on S. 1545 Before the Subcomm. on Employment, Manpower, and Poverty of the Senate Comm. on Labor and Public Welfare, 90th Cong., 1st Sess., pt. 8, at 2375 (1967):

The general objectives of the legal services program are being achieved. The

program is providing professional, good quality legal services which are proving

effective tools in the anti-poverty program.

The specific objectives of the program are to:

1. fund locally initiated and controlled programs of legal service for the people in poverty;

2. accumulate knowledge on the most effective method for bringing the assistance of law and lawyers to the poor;

3. sponsor education and research in the areas of procedural and substantive law which affect the causes of poverty;

4. acquaint lawyers with their essential role in combating poverty;

5. finance programs to teach the poor and those who work with the poor to recognize problems that can best be resolved by the law and lawyers.

Cf. National Conference on Law and Poverty, Conference Proceedincs (1965).

4 See American Bar Association House of Delegates Resolution, 90 A.B.A. REP. 110-11 (1965); Voorhees (President, National Legal Aid and Defender Ass'n), Introduction to U.S. OfFICE of Economic Opportunity, Guiderines for Legal Services Programs iv (1966):

The National Legal Aid and Defender Association welcomes the Office of Economic Opportunity's Legal Services Program. It provides means for achieving 
tive attitude regarding both means and objectives of a legal assistance program, but it is otherwise unilluminating as a program rationale. For one thing, "traditional Legal Aid" itself was a heterogeneous enterprise. For another, one of the arguments in support of LSP was that traditional Legal Aid was inadequate not only in size but in stylethat it was too tame. The official position of the ABA tended to treat this contention as false, even though most ABA members familiar with Legal Aid agreed that there was much truth in it. Be that as it may, the concept of LSP generally shared among the legal profession was a program oriented to individual clients, concerned with individual cases, and centered on the routine disorders of daily life-domestic discord, trouble with creditors and landlords, and involvements with the police, welfare agencies, and other organs of government. The instrumentality for such a program is the law office, which while publicly funded is to be essentially a replica of its fee-earning private counterpart. Its characteristic problem-solving technique is accommodationreduction of acrimony, extension of time, compromise of differences. Litigation is recognized as an appropriate weapon, but only uneasily and as a last resort. The organized bar's position, however, assumed the critical proposition under consideration here: Assisting poor people to assert their legal rights would ameliorate their impoverishment.

This proposition was also assumed in the other contending concept of the Legal Services Program. In this concept, legal assistance is the bridge between broad social grievances (e.g., bad housing, racial discrimination, expensive credit, chronic unemployment) and social reform. ${ }^{5}$ The model is the school segregation litigation which culminated in Brown v. Board of Education; ${ }^{6}$ the assumption is that what helped to end segregation in the schools (Did it?) must be able to help end privation in the poor (Why?). The reformist rationale for LSP, however, does not go very deeply into the operational connections between social grievances and this legal services mechanism. In contemplation, however, is a legal services program concentrated on group concerns of the poor, concerned with structural problems, and centered on change in the law itself-reform of welfare, school administration, and the law governing such relationships as landlord-tenant and creditor-

goals long aimed at by the NLADA and the bar-the extension of Organized Legal Aid on a scale that will make a reality of the ideal of Equal Justice under Law.

5 See, e.g., P. WAid, LAW AND Poverty: 1965 (1965); Address by Attorney General Robert F. Kennedy, University of Chicago Law School, May 1, 1964 (Law Day), in 13 U. CHI. L.S. REc. (No. 1) 24 (1965); Bamberger, Legal Aid: An Opportunity for the American Bar, 42 N.D.L. REv. 287 (1966); Pye, The Role of Legal Services in the Antipoverty Program, 31 LAw \& CONTEMP. PROB. 211 (1966).

B 347 U.S. 483 (1954); 349 U.S. 294 (1955). 
debtor? The characteristic problem-solving technique is aggressive prodding, protesting, and complaining on behalf of the poor, with litigation as a routine resort if not ordinary procedure.

For a variety of reasons it has been convenient to efface the differences between these points of view, and to avoid questioning their common assumptions. An ambiguous policy has permitted a single federal program to commence operation at a variety of local starting places, including some where no services had previously existed and some where there could already be found large and sophisticated operations. ${ }^{7}$ Moreover, none but the most sanguine reformists thought that the conservative objective of legal palliation could be ignored, and none but the most serene conservatives thought that the law needed no reform. As the program enters its fifth year, and perhaps the decisive point of political reconsideration, it thus remains as nearly all things to all men as its supporters have been able to make it.

Yet the need for clarity of purpose persists, because choices in personnel, financing, and organization require some sort of guide. The choice is an interesting one, ideological considerations to one side. The conservative, traditional concept can show proven results in the sense that it transforms some of its clients (not all of them) from very miserable and troubled people into somewhat less miserable and troubled people. However, traditional Legal Aid is expensive, so much so that it involves a seemingly bottomless pit of plausible need. The simple evidence for this is that every legal assistance office of the Legal Aid type finds itself inundated with business, unless its attitude toward

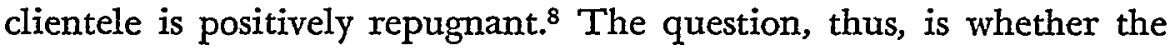
militant reformist approach has enough to recommend it to be a serious alternative.

The militant reformist approach has been variously presented in the literature. The best known statement perhaps is one by Edgar and

7 Consider that the Legal Aid Society of New York City had over 250 full-time lawyers with special branches for family court matters and for civil and criminal appeals, while the Legal Aid Society of Orange County, New York, had only one full-time attorney and will not handle cases involving bankruptcy, divorce, annulment, and separation, and the Legal Aid Society of Jersey City, New Jersey, had one full-time attorney and will not accept cases requiring court work. See National Legal Am and Defender Association, Directory of Legal Aid and Defender Services 1967-68 (1967).

8 See, e.g., Bar Association of the District of Columbia, Report of the Commission ON LEGAI, Am 140 (1958):

In the first place, the Legal Aid Bureau has never run out of work, even though its staff has fluctuated in size, as is inevitable in a volunteer system. Whether the number of attorneys be large or small, clients are almost always waiting. It is not unusual for a staff attorney to learn from a client against whom a default. judgment has been entered, that the client had previously come to the Bureau, but had to leave because of his inability to wait long enough to see an attorney. 
Jean Cahn; ${ }^{8}$ the most systematic is a monograph by Jerome Carlin, Jan Howard, and Sheldon Messinger. ${ }^{10}$ The essence of the argument may be stated as follows:

1. The substantive rules of the law in many respects affect the poor in an unfair way. Rules governing private relationships, for example between landlord and tenant, do not take adequate account of the disparate bargaining power of the parties. Rules governing eligibility for public benefits, for example welfare assistance and public education, do not recognize the real measure of the need of the poor. And, whatever the relationship governed, the rules do not take into account the fact that the poor lack the ability and the resources to enforce the rights that the law undertakes to confer.

2. The unfairness of the law in these respects could be ameliorated by providing the poor with legal assistance. Remedying the unfairness of the law, in turn, could reduce the extent to which the poor are enveloped by the sense of inadequacy and despair which characterizes their lives. Moreover-and this is the critical element in the argument - such remedial efforts would have a cumulative secondary effect of improving the poor's standard of housing, education, and general livelihood.

In attenuated form this argument also underlies the more conservative rationale for the Legal Services Program, for the ideal of "the Rule of Law" as articulated by the legal profession requires confidence that traditional legal processes can adjust conflicting expectations. On a number of critical points, moreover, the argument for augmenting legal assistance provided the poor seems hardly open to responsible dispute. There can be little question that the procedure of courts and many administrative tribunals does work unfairly on anyone who is unable either effectively to assert legal rights on his own behalf or to employ a lawyer for that purpose. The procedure of most all courts and of many agencies is based upon the adversary system. In the adversary system, the parties have the opportunity and responsibility for developing and presenting the revelant facts and legal contentions, while the adjudicator is supposed to be an essentially passive being. If the parties lack capacity to exercise this opportunity in an effective way, their claims cannot be presented in the way contemplated by the system. Yet, even where it is evident that the parties lack capacity to do this-as is typically true of the poor-the adversary structure is adhered to, and ineffective parties are allowed to suffer their fate. The result is a conflict between the system's pretension and its fulfillment,

8 Cahn \& Cahn, The War on Poverty: A Civilian Perspective, 73 Yale L.J. 1317 (1964). 10 J. GarLIN, J. Howard \& S. MESSINGER, GIVIL Justice ANd the POOR (1967). 
which may be taken as one working definition of procedural injustice. ${ }^{11}$

Deficiencies in procedural justice also appear in a less evident way in some agencies that do not employ the adversary system. Agencies administering public benefit programs-welfare, low-income housing, food allotments, etc.-apply statutes that in terms confer eligibility on all potential claimants who fall within categories defined in the statutes. The appropriations for such programs, however, are usually insufficient to provide the specified benefit for all persons actually in the category of eligibility. As a practical matter, therefore, the agency must administer the program by giving unauthorized preferences among equally eligible applicants, which may be taken as another working definition of procedural injustice. ${ }^{12}$

The argument for militant reform asserts further that these procedural malfunctions mirror conflicts in legal policy in the substantive domain. The poor have so little bargaining power that their contracts are usually contracts of adhesion-simple concurrence with terms laid down by the other party-but these contracts are generally enforced as though reached at arm's length by parties with equal bargaining power. More broadly, the poor lack vocational and consumer skills to participate effectively in an economy whose basic legal premise is that of free exchange based on intelligent individual initiative. They lack political and organizational skills to participate effectively in electoral and legislative processes which presuppose that people having grievances or interests will come forward to assert them. And certain groups of the poor-Negroes and to a lesser extent other minorities such as Puerto Ricans and Mexican Americans-suffer partial or total exclusion from forms of social intercourse which are presumed to be available to everyone.

The argument can be expanded and supporting detail supplied, but

11 If this contradiction were avoided, most of the types of procedural injustice specified in CIVIL JUSTICE AND THE POOR, supra note 10, would be avoided or substantially mitigated-"mass justice," "sewer service," the "abuse" of small claims court procedure, for examples.

12 Wickenden, Administration of Welfare Rights, in NATIONAL CONFERENCE ON LAW and Poverty, Conference Proceroings 31, 32-33 (1965):

There are two common assumptions regarding the humiliations and niggardliness of public assistance administration, both basically erroneous but comforting to the complacency of those who hold them. One, commonly held by those who consider themselves the champions of the recipient poor, is that these stringencies and oppressions reflect the deliberate cruelty or stubborn blindness of the welfare agency and its employees. The agency itself becomes the natural scapegoat for the laws it is obliged to administer and the inadequacy of the funds it must stretch to cover the desperate poverty of its clientele. But when the money available is inadequate to the need to be met the administering agency must choose between two alternatives: either cut the amount given each family or reduce their numbers by tighter eligibility requirements. 
this is an adequate summary for present purposes. So far as the Legal Services Program is concerned, however, the most perplexing question is-not whether these propositions are true, though they are often denied-but how they relate to the idea of a LSP. The suggestion advanced here is that a more coherent LSP could be evolved if the conclusions to be derived from these premises were more carefully thought through. This is no easy task. What is involved, among other things, is examining the connections between social justice (allocation of community resources) and civil justice (fairness in decision of particular cases). ${ }^{13}$ These connections are not so obvious as is widely assumed.

\section{The Race Problem}

Perhaps the most formidable impediment to careful analysis of this question is the persistent tendency to confuse the problem of poverty with that of race discrimination. These problems are, of course, related. A disproportionate number of people from racial minorities are poor, and a disproportionate number of the poor are of racial minorities. Furthermore, some poverty-and much relative economic deprivation -is the result of racial discrimination, for racial minorities are often less well received in the market place than others, and accordingly command a lesser wage or pay a higher price. But the relationship is not invariant. There are many poor whites, far more in absolute numbers than there are poor blacks, and there are many well-paid blacks. In any case, many types of injustice cited as being suffered by the poor are not suffered by white poor and are suffered by black middle-income people. This is true, for example, of all persisting instances of legally sanctioned race discrimination, of which much is made in the literature on the Legal Services Program.

It is important to differentiate between the problem of poverty and the problem of racial discrimination. They differ in ethical character, in their susceptibility to legal specification and, in consequence, in the strategies to which they might succumb.

As to ethical character: In a market economy, poverty can result from autonomous individual actions no one of which can be assigned as blameworthy even though their combined effect is to return miser-

13 The distinction is in substance that drawn by Aristotle between distributive justice and corrective justice. ARistotue, The NichoMachean ETHICs, Book V (Everyman's Library ed. D. Chase transl. 1934). One of the curiosities of philosophy is that most social and political philosophers since Aristotle seem to have been preoccupied with questions of the general good, while most legal and juristic philosophers have been preoccupied with the logic and faimess of the adjudicative function. Only in the Supreme Court of the United States is the integration of these issues unavoidable, which may help explain why that tribunal has always been so puzzling, fascinating, and controversial. 
ably small yield-for labor or goods-to some market participants. Racial discrimination, whether in the market place or in administration of public benefits, consists of decisions each one of which is blameworthy if any of them is: the wrong consists of treating a person as something less than that. "Gouging" the poor is often complained of, but it is not clear why it is wrong in a market economy for a person to demand a high price for a rare commodity (whether diamonds or milk), or to pay a low price for an abundant commodity (whether pea picking or student research assistance). On the other hand, it seems clear that it is wrong to demand more for milk (or diamonds) from a member of a racial minority, or to pay him less for equal work.

As to legal specification: The existence of racial discrimination can be established by a comparison process that is simple in concept if sometimes perplexing in application. In market transactions the market itself defines the price and (with less precision) the commodity. Selling at a different price under similar circumstances is discriminatory. ${ }^{14}$ The existence of poverty, however, cannot be established by such an empirical comparison. A determination that a person is poor requires comparison between an empirical event-what his income is-and a normative concept-what his income should be. The latter idea is legally unintelligible unless there is a statement of what is to be regarded as a minimum income, and this is a normative rather than an empirical concept.

\section{The Problem of the Wrongdoer}

These differences emerge more clearly if the question is asked, in the case of poverty, who the wrongdoers are. The "wrong" that results in poverty differs from the wrong in racial discrimination and from the wrongs for which legal remedies have traditionally existed, such as fraud or breach of contract. The wrong in fraud or contract breach (or in racial discrimination) is the act of an identifiable offender and consists of the failure to apply in a particular instance a principle of conduct that holds for all instances if it applies to any. Violation of the principle therefore can be assessed case by case. The consequences of the act so far as the victim is concerned are taken into account only for purposes of measuring damages, not assessing the act's wrongfulness as such. ${ }^{15}$

\footnotetext{
14 See M. SOVERN, LEgAL RESTRAINTS ON RaCtaL DisGRIMINATION IN EMPLOYMENT (1966); Winter, Improving the Economic Status of Negroes Through Laws Against Discrimination: A Reply to Professor Sovern, 34 U. CHI. L. REv. 817 (1967).

15 For a valid claim in litigation, the law ordinarily requires proof of actual damage to the victim as well as proof of a wrongful act by the defendant. But this rule is essentially one of public economy, limiting the employment of limited judicial resources to those cases where wrongs require material redress and not simply condemnation.
} 
The "wrong" of impoverishment, in contrast, has victims but no specific perpetrators. Impoverishment is the residue of the whole set of transactions constituting the victim's economic life. This residual consequence can be discerned not by looking at any particular transaction between the poor person and those dealing with him but only by drawing up accounts which reflect all his transactions. The "wrong" manifested in this residual consequence is remedied not by overturning any particular transaction (as is the case with usual legal wrongs) but only by changing the combined effect of all of them. Yet the complex of transactions affecting any individual poor person is the result of still further removed transactions, which determined what his buyers would pay and his sellers would charge. Case by case assessment thus becomes impossible. And selecting one or another of the purveyors to the poor as the wrongdoer-landlord and moneylender are the classical scapegoats-is purely arbitrary.

This point is often obscured by observations to the effect that the poor are victims of fraud or other wrongs. It is true that this is often the case, and that legally remedying these wrongs results in betterment of their victims. But it does not follow that remedying these wrongs is a strategy for alleviation of poverty. Discrimination and fraud are wrongs independently of whether they lead to impoverishment of their victims; conversely, the wrong of impoverishment may be suffered by those who have never been cheated or suffered racial discrimination. Such specific wrongs as violation of housing codes or usury laws are likewise misleading as indicators of an anti-poverty strategy: If there were compliance with the housing code at higher rents, the tenant would still be poor-better housed but worse fed or clothed. If there were compliance with the usury laws, the poor would simply go without credit. Of course, it is wrong to violate housing codes and usury laws, and the wrongs may be legally remedied. But such a remedy is not responsive to the wrong of impoverishment as such.

The argument for a Legal Services Program that would alleviate poverty by remedying legal wrongs hinges on this point: If the legal wrongs suffered by the poor (discrimination, fraud, breach of warranty) were remedied for the poor as a class, the poor as a class would be substantially better off. There seems to be something to this, for these wrongs add up to contract violations (social contract as well as business contracts) of epidemic proportions. And in the short run, before price adjustments are made, enforcement of these contracts at least gives the poor the benefit of their bargains. In a dynamic economy, however, and especially in an inflationary one, price adjustments are quickly made. Enforcement of their rights can thus result in the poor getting what they pay for, but it may also result in their having to pay more for 
what they get. Whether they would have to pay more depends upon the extent to which businessmen dealing with the poor have been earning extraordinary profits. The evidence on this question is presently far from satisfactory, but it hardly shows that vendors to the poor are generally realizing extraordinary net returns.

There is a corollary. The legal wrongs of discrimination, fraud, and breach of warranty that the poor suffer are also suffered by the nonpoor. Indeed, it is probable that wrongs of this kind are suffered more widely by low-middle income people than by the very poor; these wrongs are mostly associated with the market place and people with higher incomes are in the market oftener and deeper than people with lower incomes. Ralph Nader's beneficiaries are not the destitute.

In this light, the strategy of remedying poverty by righting individual wrongs is at once too narrow and perhaps misdirected. It is too narrow because it conceives of the problem of remedial injustice as central to the problem of poverty, whereas such does not appear to be the case. It is misdirected if it achieves its stated goals only at increased prices. Moreover, a "showcase" approach-remedying some social grievances but not enough to increase prices-is mere hypocrisy, the erecting of jural Potemkin Villages. A productive strategy to alleviate poverty would seem to lie elsewhere. The market place must somehow be changed in a way that influences real income and prices, or the aggregate effects of market exchanges must be offset by transfer payments-income supplements, rent subsidies, publicly provided services, etc.

A legal strategy to change the market place in a way that really influences prices is one that, first among other things, aims to eliminate legally imposed loadings on the prices that the poor-and everyone else-must pay. This problem is considered more fully in another paper. ${ }^{16}$ Suffice to say here that if litigation were employed in such a strategy, it would aim at invalidating, on grounds of substantive due process, the manifold market-rigging laws that special interest groups have succeeded in putting on the books. Unfortunately for such an approach, the Supreme Court and state appellate courts have almost completely abandoned their formerly asserted authority to invalidate legislation on this ground. ${ }^{17}$

This leaves open the possibility of trying to modify the effects of

16 Hazard, The Peculiar Legal Problems of the Poor (to be published in $25 \mathrm{~J}$. Soc. ISSUES - (1969)).

17 See McCloskey, Economic Due Process and the Supreme Court: An Exhumation and Reburial, 1962 SUP. Cr. REv. 34. 
market exchanges by schemes of taxation and redistribution. ${ }^{18}$ Such schemes are, of course, the basic stuff of legislation. The question here is whether such a legal goal can be achieved through the device of litigation. Since an individual lawsuit aims at a transfer of assets-thus being a redistribution-it would seem to follow that multiple lawsuits on behalf of the poor as a group would result in aggregate income redistribution. There are reasons for believing this prospect to be uneconomical and thus practically illusory. There are also reasons for believing it to be self-contradictory and, on this account, constitutionally and politically perilous.

The problem can be most easily stated by exaggerating its form. The condition of the poor can be thought of as the subject of a great big proceeding for adjustment of debts, class-action bankruptcy so to speak. In this imagined proceeding, the court examines the situation of each poor person, determines the net worth required for his wellbeing, calculates the revisions in his employment and purchase contracts necessary to yield that net worth, and reconstitutes the market's verdicts accordingly. Reconstitution is effected by an order for restitution in proportion to the creditor's wealth, imposing what amounts to a tax.

Only a proceeding substantially of this effect can transmute the enforcement of legal rights into income redistribution. Indeed, the imaginary aspects of the hypothetical proceeding are ones merely of size and speed as compared with the present machinery for enforcing the rights of the poor. The imagined proceeding would do what the enforcement-of-rights strategy aims to do, realize social (distributive) justice through civil (commutative) justice. But at what price?

The price is a heavy one in purely economic terms. It is difficult to imagine a more expensive way to redistribute income than by litigation. (It is difficult to imagine doing almost anything in a more expensive way than by litigation.) Creditors' proceedings are not renowned for their efficiency, nor is there reason to believe they would become more efficient with increase in size and complexity.

The cost involved is not merely the litigation overhead, however. There are fundamental constitutional and political considerations as well. These can be brought into focus by asking how the court in the proceeding we have conjured would justify its order for redistribution. The justification would not be, could not be, the same as that when a remedy is given for a legal wrong of the type normally adjudicated.

18 See W. Blum \& H. Kalven, The Uneasy Case for Progressive Taxatyon (1953); H. Simons, Personal Income TAXation (1938). 
Wrongs remedied in normal adjudication can be reduced to a statement in the following form:

The defendant has failed to give plaintiff that which is plaintiff's own. ${ }^{19}$

"Own" in this formulation is not figurative; it implies a tenable claim under presently recognized law. The justification for awarding the remedy is the rule of law referred to. A judge can in conscience make the award on this basis, and the community can accept his doing so.

Justification for income redistribution cannot take this form. By hypothesis the grievance is that the "wronged" person doesn't own enough. To say that society "owes" him something, or that he "really" owns a part of someone else's property (as Marx, for example, argued), is simply a figurative way of saying that there should be a redistribution of income. But income redistribution requires not only a giving to those who lack but also a taking from those who have. Since the taking cannot be justified by reference to ownership rights, it reduces itself to expropriation (if done by one to another) or self-denial (if done by one to himself). The legislature being representative can engage in self-denial, vicariously but genuinely, knowing that it will be reminded when its generosity becomes excessive. A court being unrepresentative can only engage in expropriation if it does not follow the law. ${ }^{20}$

To formulate a program for remedying poverty in terms of the vindication of legal ownership rights thus involves self-contradiction. By implication it accuses the general community not merely of indifference but also of dishonesty-the dishonoring of ownership rights of the poor-which is quite something else. Of course, such a formulation admits of righteousness in rhetoric that can't quite be reached in arguing about economic imbalance. But that only makes the point involved in a different way: To assimilate the "wrong" of poverty to the wrong of fraud or that of racial discrimination involves perversions of language, logic, and ethics. To try to sustain a program with such perversions is only to engender further confusion and resentment.

The constitutional aspect of this difficulty is simple: Taxation with-

19 Claims for property take this form explicitly. Contract rights are inchoate property, and tort remedies are involuntary conversions of assets or interests into compensation money. Injunctions issue in anticipation of wrongs to property, contract, or other interest.

20 Maintaining the legislature as a genuinely representative body thus emerges as the complement in political morality to the proposition that courts should refrain from exercises in distributive justice. Hence, the constitutional importance of Baker v. Carr, 369 U.S. 186 (1962), which made legislative apportionment subject to judicial review. Hence also, the willingness of many otherwise ill-disposed members of Congress finally to go along with strict legal protection of the right to vote in the Voting Rights Act of 1965. 42 U.S.C. $\S \S 1971,1973$ et seq. (Supp. IV, 1969). 
out representation is tyranny. Its political aspect is suggested by considering what happens when a grievance is put in the form of a legal demand. To put the poor's claim for income redistribution in this form entails polarizing the issue as one of the poor's need as against everyone else's responsibility; stigmatizing the intended beneficiaries in the course of proclaiming their plight; and forcing a problem of compassion into the mold of obligation. The ad hominem attack involved in this sort of formulation has not been inevitably successful when directed against "the rich." It is almost certain to be unsuccessful when directed against those who pay the bills in America today-the middle classes, of whom many are themselves near the "poverty line."

The Place of Civil Justice in Social Justice

In this perspective, attempting to translate the procedure of civil justice into the objective of social justice doesn't work out very well. Civil justice-Aristotle's commutative justice-involves enforcement of property claims recognized by law. Social justice involves transfers of property interests, through regulation or taxation, by means of law operating posterior to the formation of property. The one can be converted into the other only by bending both logic and constitutional authority. Because constitutional bending reaches a political breaking point, that conversion seems unwise as a strategic aim for a Legal Services Program.

Yet it does not follow that there is no relation between civil justice and social justice. For one thing, living political institutions never operate in the pure form of their constitutional conception. Hence, the courts can accept some invitations to work distributive justice in the guise of adjudicating legal rights. But the invitations have to be issued in restricted number, a matter of prudence which exuberant povertyists seem disinclined to exhibit.

For another thing, the courts are open for public hearings as a matter of right, whereas legislatures are not always so hospitable. The legal assertion of a claim is a political event, sometimes a significant one, even if the claim is rejected. In our tradition it is thus a function in fact if not in concept for the courts to be forums for political grievance. And so long as legislatures prefer not to listen to poor people's troubles, it may be politically salubrious for the courts to attempt part of the redistributive job.

Moreover, there remain the numberless instances in which the poor suffer what are unmistakably legal wrongs: fraud, discrimination, and unfair procedure. They suffer also the involvements of criminal accusation, domestic conflict and breakdown, and troubles arising out of the 
mismanagement of money. These wrongs and involvements correspond to traditional and commonly recognized conceptions of what legal rights are and what legal remedies ought to be. We conclude from preliminary analysis of survey findings ${ }^{21}$ that providing legal assistance to help right these wrongs and disentangle these involvements conforms to poor people's ideas of what legal assistance would entail. Providing that assistance at public expense is of itself the making of an income redistribution, to the extent of the value of the services provided. This is so without regard to the income-redistributive effects of remedies awarded in particular cases in which the legal assistance is provided, or in all such cases considered as a whole. The redistributive effects achieved in particular cases are largely fortuitous; those achieved in all cases considered as a whole may be, for the reasons suggested earlier, largely illusory. What remains, if it is worth the cost, is securing the poor in the knowledge that they get an even procedural break before the law.

In this perspective, the contribution of civil justice to social justice is diffuse, microcosmic, and dull. Such a program of civil justice does not command the attention, let alone the vocation, of the inventive and passionate minds who have articulated the militant reformist concept of the Legal Services Program. ${ }^{22}$ On the other hand, it may serve the needs of the poor. And it leaves the matter of providing social justice where it ought to rest: on the conscience of the community, and its sense of prudence, as expressed in its legislation. A strategy of cooperation concerning claims formulated as appeals to conscience and self-protection might succeed. ${ }^{23}$

\footnotetext{
21 American Bar Foundation, Research Study to Assess the Need for Utilization of Legal Services by the Poor, Office of Economic Opportunity, CAP 67-7075, Research Contract No. OEO-4047.

22 Sparer, The Poor Man's Lawyer and Governmental Agencies, in Natronal Conference on Law and Poverty, Conference Proceedings 37, 46-47 (1965):

Militant advocacy by lawyers-whether on behalf of a particular impoverished individual before a large state bureaucracy, or on behalf of a group of poor persons in a local planning board-is not only for the purpose of obtaining an extra benefit and relieving the material burden of poverty, if ever so slightly. Equally, if not more important, such advocacy affects the quality and independence of life for the human beings involved. It makes real ... the knowledge that he or she is not simply an object to be manipulated or forgotten.

23 cf. E. Cahn, The Sense of Injustice (1949).
} 